\title{
ABORTION AS A VICE CRIME: A "WHAT IF" STORY
}

\author{
JOHN KAPLAN*
}

I

\section{Introduction: Abortion as a Vice Crime}

Until 1973, the year of the Supreme Court's landmark abortion decision, Roe v. Wade," a list of "vice" crimes might have included drug offenses, gambling, pornography, prostitution, consensual homosexual behavior, and abortion. Part of the justification for grouping abortion with these other offenses was its link with illicit sexuality, which clearly was seen as a vice. However, the most important reason was simply the functional one that the problems encountered in the enforcement of the abortion laws were in many practical ways quite similar to those met with in the suppression of the other vice crimes. Indeed, the use of the term "vice" to designate these crimes might be in part an artifact of police organization, since the vice squad often had jurisdiction over more than one of these offenses.

Additionally, the other names by which these crimes were known posed at least as many difficulties. For instance, calling them "victimless" crimes is an invitation to acrimonious dispute. To be sure, a vice crime must be an activity which is willingly engaged in by its participants. Rapes have never been regarded as vice crimes. In the case of some vice crimes, particularly the drug and gambling offenses, one might argue that a participant, the consumer, is victimized because of his or her own weakness; in others, such as prostitution, one might regard both participants, the seller as well as the buyer, as victims. Moreover, if pornography leads to rape, as is argued by some in the academic community, ${ }^{2}$ then its victims are neither the seller nor the buyer, but rather the innocent women who are attacked. In addition, others charge that society in general, including friends and family of the participants, are also harmed by, and thus are victims of, the forbidden conduct. ${ }^{3}$

\footnotetext{
Copyright $(0) 1988$ by Law and Contemporary Problems

- Jackson Eli Reynolds Professor of Law, Stanford University. This research was supported by the Stanford Legal Research Fund, made possible by a bequest from Ira S. Lillick and by gifts from other friends of the Stanford Law School.

1. 410 U.S. 113 (1973).

2. See E. Donnerstein, D. Lintz \& S. Penrod, The Question of Pornography 86-107 (1987); attorney General's Commission on Pornography-Final Report 326 (1986); Donnerstein, Aggressive Erotica and Violence Against Women, 39 J. Personality \& Soc. Psycholocy 269 (1980); Malamuth, Rape Fantasies as a Function of Exposure to Violent Sexual Stimuli, 10 Archives of Sexual Behav. 33 (1981).

3. See Kaplan, The Role of the Law in Drug Control, 1971 DuKE L.J. 1065, 1075-76; see also Aids and the Sexual Counter-Revolution, NAT'L. Rev., July 3, 1987 at 19 (discussion of the irrelevance of the "victimless" classification).
} 
Of all the vice crimes, the labelling of abortion as a victimless offense provokes the angriest outcry. A large and vocal group regards calling abortion a victimless crime as a positive affront, on the ground that it not only decides what they consider to be the very question at issue, whether or not a fetus is a person, but also, in their view does so wrongly.

For most vice crimes, the use of the term "consensual" provokes much less acrimony than does "victimless." This term does not appear to pass judgment on the issue of whether there is a victim to the activity. It also succeeds in focusing on a practical aspect of all the vice crimes: Those involved have consented, do not see themselves as injured, and do not complain to the police. The consequences of this silence for the criminal investigation and enforcement of the laws against these behaviors have been detailed elsewhere-most notably by Herbert Packer in his landmark book, The Limits of the Criminal Sanction. ${ }^{4}$ These crimes are characterized by a low number of arrests compared to the amount of criminal activity, problems of selective prosecution, police reliance on a whole series of intrusive and expensive means of investigation, such as the use of informants and decoys, and a high level of payoffs to the police and other forms of corruption. ${ }^{5}$

When used in reference to illegal abortion, however, the term consensual is not a great deal better than victimless. It merely underscores that the fetus, which the foes of abortion regard as a human being, has not consented to anything. Under this view one might argue that homicide, leaving no victim who can complain to the police, is equally consensual. Of course, the difference is a practical one. The difficulty of disposing of a human body so that no traces are left for forensic examiners is well known; and human beings usually have family members and acquaintances who often ask after them and go to the police if the answers are not satisfactory. These factors make homicide far more similar to the crimes with victims who complain than to the victimless, consensual, or vice crimes.

There are two additional reasons to classify abortion as a vice crime. Abortion was perceived by a sizable (and, until 1973, a dominant) segment of the population as wicked. Polls indicated that a few years before Roe $v$. Wade, the great majority of the public perceived abortion, even in the first trimester of pregnancy, as inappropriate, except in a narrow range of circumstances such as where the mother's life was endangered or the pregnancy arose from a rape. ${ }^{6}$ In fact, the legislatures of the great majority of states had spoken clearly against the practice. ${ }^{7}$

Similarly, the element of moral dissension, present in all the vice crimes, was especially clear with respect to abortion. Those who performed and underwent abortions prior to Roe $v$. Wade rejected the prevailing moral view. Indeed, the disagreement was perhaps more widespread as to abortion than

4. See H. Packer, The limits of the Criminal Sanction 151-52 (1968).

5. Id. at 329-30.

6. See Opinion Roundup: Abortion, Public Opinion, April/May 1985, at 27.

7. Roe v. Wade, 410 U.S. 113, 118 (1973). 
as to any other vice crime with the possible exception of gambling. In 1965, only about 15 percent $^{8}$ of the population were in favor of making abortion legal "under all circumstances." On the eve of Roe $v$. Wade, a considerably higher portion of the public agreed. 9

There are, however, two problems with characterizing abortion as a vice crime. First, one of the connotations of vice is that it is pleasurable to the person engaged in the activity. Gambling may not meet this requirement, if practitioners are motivated more by hope of financial gain than by pleasure. Similarly, many heroin addicts report that they seek a fix, not to feel good, but to feel "normal" and to avoid feeling bad. ${ }^{10}$ Nonetheless, at least in the public mind, and for the most part in actuality, the idea of pleasure-seeking does seem involved in the crimes ordinarily grouped under the heading of vice." This is not the case with respect to abortion.

The second connotation of vice which cuts against including abortion under that heading is that vice generally connotes a repetitive activity or habit. While all of the other vice crimes are repeated quite frequently by those who commit them, getting an abortion is quite a different kind of behavior. Apparently, most women receiving abortions before Roe $v$. Wade were doing so for the first time, ${ }^{12}$ as is still the case today. ${ }^{13}$

In fact, the concepts of victimless, consensual, and vice crimes are somewhat fuzzy around the edges. After all, bribery certainly fits the description of a crime where neither participant considers himself a victim, and hence, is not reported to the police. Although bribery is similar to the vice crimes in the means by which its prohibition must be enforced, it is not considered a vice because no moral dissension exists on the issue. Had Mark Moore come along earlier with the term "invisible" crime, it would have been a better, more functional, and less divisive nomenclature for all these crimes. ${ }^{14}$ For the moment, the important fact is that the similarities among all of these crimes, abortion before Roe $v$. Wade included, greatly outweigh the differences.

Whether abortion, where it is illegal, is classified as either a vice, consensual, victimless, or invisible crime turns out to be extremely important for predicting a society's response to the practice.

\footnotetext{
8. See Opinion Roundup, supra note 6 , at 27.

9. Id.

10. See J. Kaplan, The Hardest Drug: Heroin and Public Policy 27-31 (1983).

11. For a general discussion of pleasure and vice crimes, see J. Kaplan \& J. Skolnick, Criminal JUSTICE 28-37 (4th ed. 1987).

12. See N. Lee, The Search for an Abortionist 37 (1969).

13. C. Tietze \& S. Henshaw, Induced Abortion: A World Review 119 (6th ed. 1986).

14. See Moore, Invisible Offenses: A Challenge to Minimally Intrusive Law Enforcement, in ABSCAM EThics 21-23 (G. Caplan ed. 1983).
} 
II

\section{The Future of ROE $V$. WADE}

The chances are, that at the time of the first election of Ronald Reagan as President, most careful observers of the Supreme Court would have granted a relatively short life expectancy to Roe $v$. Wade. ${ }^{15}$ The appointment of believers in "strict construction" or "judicial restraint" was high on President Reagan's list of priorities. ${ }^{16}$ Strict constructionists oppose giving constitutional protection to rights, such as the right to privacy, ${ }^{17}$ that are not specified in the Constitution. They also oppose any entry by the Supreme Court into areas of political controversy, especially if this entry is on the liberal side. ${ }^{18}$ On both of these grounds, the Supreme Court's abortion decision stands out as the preeminent target.

At the time of Ronald Reagan's inaugural, the average age of the justices who espoused the majority opinion in Roe $v$. Wade was nearly 73 years. ${ }^{19}$ It was expected, then, that if the president were elected to two terms, he would be able to fill several vacancies on the court. Moreover, although technically Roe $v$. Wade was a seven to two decision, ${ }^{20}$ most observers regarded the vote of one of the majority, the Chief Justice, as, at the very least, shaky. ${ }^{21}$ His concurrence with the result emphasized his agreement with the majority on the understanding that it did not permit abortion on demand. ${ }^{22}$ However, insofar as the first trimester of pregnancy is concerned, the majority opinion clearly does permit abortion on demand. ${ }^{23}$ It was alleged, even at the time of the decision, that the Chief Justice voted as he did solely so that he could exercise his prerogative, as a member of the majority, to assign the writing of the opinion. Then, as soon as the Court was within one vote of overruling the decision, he would switch to make a new majority. ${ }^{24}$ In fact, he never got this opportunity. However, some evidence in support of this viewpoint is that

15. See The Reagan Court, N.Y. Times, Oct. 1, 1980, at A26, col. 1; see also Turner, Reagan Says He Would Not Use Single Issue Test to Pick Judges, N.Y. Times, Oct. 2, 1980, at A 1, col. 2.

16. See The Great Debate: Interpreting our Written Constitution, Address by President Ronald Reagan at the Investiture of Chief Justice William H. Rehnquist and Associate Justice Antonin Scalia, reprinted in The Federalist Society 53-56 (1986).

17. Id.

18. Id.

19. See Roe v. Wade, 410 U.S. 113, $113-15$ (1973). The vote was as follows: Majority: Justices Blackmun, Marshall, Brennan, and Powell; Concurred: Justices Burger, Douglas, and Stewart; Dissented: Justices Rehnquist and White. On January 20, 1981, their ages were as follows: Blackmun, 72; Marshall, 72; Brennan, 74; and Powell, 73.

20. Id.

21. See, e.g., The Week the Supreme Court Changed Colour?, Economist, July 4, 1987, at 25.

22. 410 U.S. at 208 (Burger, C.J., concurring) ("I do not read the Court's holdings today as having the sweeping consequences attributed to them by the dissenting Justices; the dissenting views discount the reality that the vast majority of physicians observe the standards of their profession, and act only on the basis of carefully deliberated medical judgments relating to life and health. Plainly, the Court today rejects any claim that the Constitution requires abortion on demand.").

23. 410 U.S. at 164 ("For the stage prior to approximately the end of the first trimester, the abortion decision and its effectuation must be left to the medical judgment of the pregnant woman's attending physician."').

24. B. Woodward \& S. Armstrong, The Brethren 169-74 (1979). 
shortly before his retirement, and indeed at his last opportunity to do so, the Chief Justice did announce his recantation. ${ }^{25}$

The majority in Roe v. Wade has lasted surprisingly long. Only two vacancies appeared in the first six years of the Reagan presidency, ${ }^{26}$ and one of these, Chief Justice Burger's, was always considered a vote to overrule the case at the opportune time. With the resignation of Justice Powell, there seem to be four solid votes in favor of the retention of Roe v. Wade (Justices Blackmun, Brennan, Marshall, and Stevens). Whether the first two Reagan appointees (Justices O'Connor and Scalia) and his latest appointee (Justice Kennedy $)^{27}$ are prepared to overrule Roe $v$. Wade is uncertain, but there is certainly no reason for confidence that they will not. ${ }^{28}$

Of course, few things in the world of law, any more than in politics, or indeed in almost any other field of human endeavor, are certain. Miranda $v$. Arizona ${ }^{29}$ was also a target of the Reagan presidential campaign, and the two Nixon campaigns earlier. ${ }^{30}$ In fact, no president has had a good word to say about that decision since its promulgation by a 5-4 majority in 1965 . Notwithstanding a significant pruning and restriction, however, Miranda has yet to be overruled.

Two factors, however, indicate a shorter life expectancy for Roe v. Wade. First, a sizable part of the conservative constituency which would be expected to argue for the overruling of Miranda has already come to terms with the decision and fears that if the decision is overruled it might be replaced by something worse, at least from the police viewpoint. Those opposing abortion show no signs of coming to terms with Roe $v$. Wade.

Second, technological development may have undermined a considerable portion of the scientific reasoning behind Roe $v$. Wade. The age at which fetuses are viable has declined with medical advances, and the safety of childbirth has been greatly improved. ${ }^{31}$ To the extent that the Supreme Court decision was based on these factors, and there is at least some language in the Court's opinion to suggest this, ${ }^{32}$ it has been made partially obsolete by

25. Thornburg v. American College of Obstetricians \& Gynecologists, 106 S. Ct. 2169, 2190 (1986) (Burger, C.J., dissenting) ("I regretfully conclude that some of the concerns of the dissenting justices in Roe, ... have now been realized.").

26. Justice Stewart was replaced by Justice O'Connor in 1981 ; Chief Justice Burger was replaced by Associate Justice Rehnquist, whose position was in turn taken by Justice Scalia in 1986.

27. Justice Powell was replaced by Justice Kennedy in 1988.

28. See Akron v. Akron Center for Reproductive Health, 462 U.S. 416,452 (1983) (O'Connor, J., dissenting) ("Nonetheless, it is apparent from the Court's opinion that neither sound constitutional theory nor our need to decide cases based on the application of neutral principles can accommodate an analytical framework that varies according to the (stages) of pregnancy, where those stages, and their concomitant standards of review, differ according to the level of medical technology available when a particular challenge to state regulation occurs.").

29. 384 U.S. 436 (1965).

30. See L. Baker, Miranda: Crime, Law \& Polrtics 245-46 (1983); see also Shenon, Meese Article Attacks Rule on Warming Suspects, N.Y. Times, Jan. 23, 1987, at N9, col. 1.

31. See Rhoden, Trimesters and Technology: Revamping Roe v. Wade, 95 YALE L.J. 639-41 (1986).

32. E.g., Roe v. Wade, 410 U.S. 113, 163 (1973) ("With respect to the State's important and legitimate interest in the health of the mother, the 'compelling' point, in the light of present medical knowledge, is at approximately the end of the first trimester."). 
these advances. The importance of the technological developments is not that they require that the decision be overruled. Rather, it lies in their effect on a Justice who would not have been in favor of the decision initially but who believes that stare decisis is a barrier to overruling it. The technological changes provide an intellectually respectable argument in support of such a Justice's predilections.

If Roe v. Wade is not overruled, what follows will be merely a long thoughtexperiment. It will be worthwhile for whatever light it sheds upon the nature of our vice laws, and for any effect it may have upon the dialogue over a constitutional amendment to overturn the abortion decision. On the other hand, if Roe $v$. Wade is overruled, what follows may be a look into the future.

\section{III}

\section{The Political Battle}

Overruling Roe v. Wade would by no means end the political battle over abortion. That case simply rendered unconstitutional state statutes forbidding abortion. If Roe $v$. Wade were overruled, the law would not automatically return to the status quo ante and recriminalize abortion. Before these changes could occur, in nearly every state, the legislature would have to pass, and then the governor sign, a new statute. In some states, the old antiabortion statutes have been repealed, simply as a housekeeping matter, to get rid of what were seen as unconstitutional restrictions. ${ }^{33}$ In other states, the statutes criminalizing abortion have been repealed as part of a new statutory scheme which the draftsmen thought would have a better chance of passing Supreme Court muster. ${ }^{34}$ Moreover, if the putative overruling of Roe v. Wade were to be incomplete, and a new decision required certain exceptions or formalities to be put in place before an anti-abortion law could be held constitutional, the passage of new abortion laws might be necessitated in all states, as was the case some years ago with respect to capital punishment.

It is not unrealistic to think that for some considerable time after any overruling of Roe $v$. Wade, abortion would be illegal in some states while remaining legal in others because of an inability to pass the requisite criminalizing statutes. Capital punishment, for example, is supported by an estimated 68 percent to 80 percent of Americans, ${ }^{35}$ and hence is considerably more popular than anti-abortion laws. However, the death penalty is still not in place in thirteen states and the District of Columbia, ${ }^{36}$ even eleven years after the Supreme Court's decision validating capital punishment. ${ }^{37}$

33. See, e.g., Therapeutic Abortion Act of 1987, Cal. Health \& SAfety Code \$ 25950-25958 (amended 1971, 1973, 1974, 1976, and 1987).

34. See, e.g., Illinois Abortion Law of 1975, Ill. ANN. Stat. $\S 81-21$ to 81-35 (amended 1979 and 1984). This replaced the old Illinois Abortion Law that existed pre-Roe v. Wade (ILL. ANN. STAT. $\S \S 23-1$ to $23-3$ (1981)).

35. See Opinion Roundup: The Death Penalty Considered, Public Opinion, June/July 1985, at 38-39.

36. J. KAPLAN \& J. SKOLNICK, supra note 11 , at 619.

37. Gregg v. Georgia, 428 U.S. 153 (1976); F. Zimring \& G. Hawkins, Capital Punishment and THE AMERICAN AGENDA 45-47 (1986). 
Failure to reinstate the death penalty is not primarily due to the concentration of its opponents in particular jurisdictions. It appears that a solid majority of citizenry of every state supports the death penalty for murder. In some states a fairly broad consensus among the political elite has been able to block the enactment of the death penalty-especially in states such as Michigan which lack a tradition of capital punishment. ${ }^{38}$ In others, popular governors or entrenched legislative leaders have, as a matter of conscience, prevented the enactment of such laws, without any noticeable loss of public popularity. ${ }^{39}$

Probably the most important problem in enacting anti-abortion laws is that, nationally, the public is almost evenly split on the issue. ${ }^{40}$

It must be remembered that Roe $v$. Wade at least did not come out of the blue. In the decade before Roe $v$. Wade, at least eighteen states had liberalized abortion laws, most of them in the five years before 1973.41 Of these states, four, ${ }^{42}$ by statute, permitted essentially free abortions, and several others, including California, applied a somewhat restrictive statute to provide what amounted to abortion on demand. Although a backlash set in shortly after Roe v. Wade, it must not be forgotten that, at the time, the case seemed to many to be the culmination of a national (indeed international) movement to relax abortion laws.

Today, after the popular backlash has reached what appears to be a steady state, the even balance on whether to permit abortion on demand is striking. Thus, in one poll the public split almost evenly on whether abortion should be allowed because the "family has low income and cannot afford any more children;" the woman "is not married and does not want to marry the man;" or the woman "is married and does not want any more children." 43 Similarly, the Gallup poll, in 1986, asked its population sample this question: "The U.S. Supreme Court has ruled that a woman may go to a doctor to end pregnancy at any time during the first three months of pregnancy. Do you favor or oppose this ruling?" 44 Nationwide, 45 percent said "yes," 45 percent said "no," and 10 percent had no opinion. ${ }^{45}$

Support for the Supreme Court's decision varies significantly by region. In the East and West, a favorable view of the Court's decision leads by 50 percent to 39 percent and 52 percent to 39 percent respectively. ${ }^{46}$ In the Midwest, both views tie at 46 percent, ${ }^{47}$ and in the South, the ruling is opposed by 52 percent and supported by 36 percent. ${ }^{48}$

38. See R. Schwed, Abolition and Capital. Punishment 14 (1983).

39. F. ZimRing \& G. Hawkins, supra note 37 , at 36-45.

40. See Opinion Roundup, supra note 6, at 27.

41. Roe v. Wade, 410 U.S. 113,140 (1973).

42. Id.

43. See Opinion Roundup, supra note 6, at 27.

44. See G. Gallup, Jr., The Gallup Poll, Feb. 20, 1986, at 49 .

45. Id

46. Id.

47. Id. at 50 .

48. Id. 
It is likely that a complicating factor in the effort to pass anti-abortion laws in the different states would be the great variation in the public acceptance of various reasons for abortion. Nationally, the public is overwhelmingly (about 80 percent) in favor of recognizing a woman's right to have an abortion where the child was conceived "as a result of rape;" where there is a "strong chance of serious defect in the baby;" and where the "woman's health is seriously endangered." 49

Anti-abortion forces are likely to split between those who are willing to compromise as to these exceptions and those who will remain steadfast in their opposition to abortion for any reason. The "right-to-life" partisans are more likely to see the issue as a moral one; thus, compromise to achieve acceptable legislation will be difficult. Anyone who regards abortion as murder will not tolerate lightly even those abortions which 80 percent of Americans do find acceptable. Indeed, one of the exceptions to an antiabortion law which would have support from all but the ardent anti-abortion activists is where the baby is likely to be born seriously deformed or otherwise defective. However, the anti-abortion activists seem to be virtually unanimously and vehemently opposed to this. ${ }^{50}$

Even the activists are split on some issues. Catholic doctrine does not permit abortion even where childbirth might result in the death of both mother and child. ${ }^{51}$ One historian states that Francis B. Kenrick, the Bishop of Philadelphia, took the position in $\mathbf{1 8 4 1}$ that, "two deaths were better than one murder." 52 Indeed, this very dispute was a factor that contributed to the failure of a constitutional amendment to overturn Roe v. Wade. ${ }^{53}$

There are other obstacles to compromise that would make the legislative struggle especially contentious. Support for an exception where the psychological health of the woman is in danger falls somewhere between the reasons for abortion which the great majority of the population will accept and those upon which the public is equally divided. The concern stems, however, from the likelihood that women desiring an abortion could routinely get a psychiatric opinion in their favor, and that such a standard might become the equivalent of abortion on demand. Indeed, the British Abortion Act of $1967,{ }^{54}$ which is usually considered to provide abortion on demand, merely provides that the abortion may be performed if it is certified by "two registered medical practitioners" that "the continuance of the pregnancy would involve risk to the life of the pregnant woman, or of injury to the physical or mental health of the pregnant woman or any existing children of

49. See Opinion Roundup, supra note 6, at 27.

50. See K. Luker, Abortion and the Politics of Motherhood 149 (1984).

51. See Suro, The Papal Visit, N.Y. Times, Sept. 20, 1987, at A1, col. 1; The Vatican on Birth Science, N.Y. Times, Mar. 11, 1987, at A15, col. 2; Berger, Catholic Dissent on Church Rules Found, N.Y. Times, Nov. 25, 1987, at A7, col. 1; see also J. McCartney, Unborn Persons (1987).

52. K. LuKer, supra note 50, at 31; see also F. Kenrick, TheOlogiae Moralij 110-13 (1861).

53. See Proposed Constitutional Amendment on Abortion, Hearings before the House Comm. on the Judiciary, 94th Cong. 2d Sess. 310-12 (1976); see also Hearings on a Human Life Bill, Senate Judiciary Comm., 99th Cong. lst Sess. (S. 158 H.R. 900) (1981).

54. Abortion Act, 1967, ch. 87, in Public General Acts and Measures of 1967, part II at 2033. 
her family, greater than if the pregnancy were terminated." 55 At the very least, one can say that the political donnybrook which consideration of antiabortion laws will bring on makes any prediction of the state-by-state outcomes even more uncertain.

Finally, consideration of the interplay between the legislature and the popular vote in an initiative or referendum further complicates the matter. The anti-abortion activists, for various reasons including their high level of commitment, have considerably more political power in state legislatures than their numbers alone would indicate. It is likely, however, that in popular votes where individual political figures need not fear retaliation, the antiabortion forces will do far less well. In fact, even in Massachusetts, which one might have predicted would be a staunchly anti-abortion state, a referendum to prevent public financing of abortions was soundly defeated. ${ }^{56}$

\section{IV}

\section{The Legal Patchwork}

While it is difficult to speculate on the pattern of states which would ban abortion, unless solid and large areas of the nation do this, it is hard to think of a better recipe for an unenforceable policy. The policy would be unenforceable not because the criminal laws against vice crimes are so difficult to enforce. Rather, as long as going to an area where abortion is legal is easier than violating the law, abortions performed will not even be illegal. Assuming the demand for abortion is relatively inelastic, since those who want abortions want them very much, it is unlikely that the restriction would be of major significance. The marginal reduction in abortions will come from among the very poor ${ }^{57}$ who are unable to afford transportation to states where the practice is permitted. For instance, it would not make much practical sense for New Jersey to attempt to forbid abortion to its residents so long as New York permits it.

The dilemma of states that permit abortion but lie near others that forbid the practice is a difficult one. States can subvert their neighbors' abortion policies in a way that they cannot with respect to capital punishment. Indeed, a state's restrictive abortion policy is even more easily undermined than its policy in the area of guns, cigarettes, or liquor. At least in these latter cases, the bringing of contraband into a state from another state that does not have the same prohibition or high tax rate can be inhibited by searches at the border and arrests for possession of contraband in the receiving state.

A state which forbids abortion might attempt to criminalize a resident's temporary departure from the state to receive an abortion. However, such a

55. Id. at 2034 .

56. The referendum was rejected. Yes: 673,311; No: 935,419, See A Summary of Questions on the Ballot in Mass., Boston Globe, Nov. 4, 1986, at 23, col. 1. See also Greenhouse, $A$ Turning Point on the Abortion Issue?, N.Y. Times, Nov. 13, 1986, at B10, col. 3.

57. For a discussion of the effect of the cost of abortion on the poor, see Cates, The $H y d e$ Amendment in Action, 246 J.A.M.A. 1109 (1981). 
prosecution not only is fraught with difficulties of proof, invasions of privacy, and perhaps even constitutional problems, but it also has the great disadvantage of bearing down upon the consumer of the illegal service rather than, as is usually the case, the provider.

Interestingly, even before Roe $v$. Wade, the woman who obtained an abortion was typically not made a criminal. ${ }^{58}$ Society viewed her more as a victim, forced by her own need into the toils of the abortionist. Perhaps more importantly, charging the woman with a crime might make her less likely to cooperate in a prosecution of her abortionist. If she were found guilty of any crime, in many states she would be treated as an accomplice, and as such her testimony against the abortionist would then have to be corroborated.59 Probably the most important reason for not making the woman a criminal was that there were simply far too many women who obtained abortions for the state to prosecute all of them.

A state cannot effectively prevent its citizens from receiving abortions in other states by inhibiting information as to where out-of-state abortions may be performed. ${ }^{60}$ Any such attempt would raise difficult first amendment issues and would probably be unenforceable as well. Even if a state could prevent advertisements from reaching its citizens and deter personal communications within the state directed toward getting an out-of-state abortion, this would not be nearly enough. All that the New Jersey resident in search of an abortion needs to know is that the procedure is available in New York. If further information is available there, that is probably sufficient to subvert New Jersey's policy almost completely.

The problem might run deeper than one state's simply adhering to its own public policy, indifferent to that of its neighbor. Often, states deliberately subvert the policy of their neighbors for the purpose of advancing their own interests. Thus, Nevada's divorce law for some time brought a great deal of business into the state, while subverting the policy of other states, and its legalization of gambling and perhaps even prostitution has had the same effect. Many states have lotteries which are designed to subvert the antigambling policies of their neighbors. It is likely, too, that New Hampshire's tax on liquor would be higher if that state could not count on the large purchases by Massachusetts residents seeking illegally to avoid the high liquor taxes of their home state.

\section{V}

\section{FEDERAL INTERVENTION}

Presumably, if the political battles fought within states result in a national patchwork, where some states prohibit and others allow abortion, the major

58. See, e.g., N.M. STAT. § 40A-5-3 (1953) (making the abortionist criminally liable).

59. See N.Y. Crim. Proc. LaW $\$ 60.22$ (McKinney 1981).

60. Bigelow v. Virginia, 421 U.S. 809 (1975) (Advertisements for abortion services in another state, where abortion is legal, are not stripped of first amendment protection in states where such services are prohibited.). 
anti-abortion effort would have to move to the national level. Anti-abortion groups would inevitably bring pressure upon the Congress to throw its entire weight against abortion. There are various ways this might be done. One is by making the performance of an abortion, subject to certain narrow exceptions, a federal crime. Another is by passing a law which threatens to withhold from any state which permits abortions, the very large amounts of federal funds ${ }^{61}$ for medical care for other social services which are absolutely necessary to the states' meeting what they see as their obligations.

Though this latter course would most likely coerce recalcitrant states into banning abortion, neither of these options is particularly attractive. Making abortion a federal crime might raise serious constitutional issues, and while withholding federal funds would be much less vulnerable to this type of attack, it would likely result in a situation where the states which are forced to make abortion illegal might be extremely lackadaisical in enforcing their laws. Moreover, the equal popular balance on the issue and the strength of the federalism concerns involved would probably prevent either solution from being politically acceptable.

The thrust of attempted anti-abortion legislation might be somewhat different. The most common way the federal government has intervened to prevent one state from frustrating the policy of another has been through the direct use of the interstate commerce power, instead of attempting to change the law within any state. Thus, Congress could make it a crime to travel in interstate commerce to obtain an abortion. Though there are numerous analogies to this in our federal criminal jurisprudence, ${ }^{62}$ such a solution does not seem well adapted to the abortion problem. Indeed, it would face many of the same problems encountered by a state statute seeking to control the travel of that state's residents.

It is likely that a statute making it a federal crime to perform an abortion on a resident of another state would be seen as better adapted to the problem. The closest analogy to this would be the laws presently in place that prevent gun dealers in one state from selling guns to residents of other states if the guns are illegal there. ${ }^{63}$ Given the differences in viewpoint on abortion among Americans, a forceful argument might be made that the federal government, rather than taking sides on the question, would be leaving that decision to the individual states and only intervening to prevent one state from subverting another's public policy.

Unless and until this or something like it is done, any anti-abortion laws passed in the wake of an overruling of Roe $v$. Wade could so easily be evaded

61. Consider, for example, a 1970's law restricting federal highway improvement funds from states not enforcing $55 \mathrm{mph}$ speed limit. See Koza, Drivers Ignore $55 \mathrm{mph}$ Limits; May Cost State Highway Aid, Los Angeles Daily J., Dec. 3, 1980, at 1 , § II, col. 1 .

62. See, e.g., 18 U.S.C. $\$ 1821$ (1948) (making the transportation of dentures into states with local monopolies illegal). See also White-Slave Traffic (Mann) Act, ch. 395, 36 Stat. 825 (1910) (codified as amended at 18 U.S.C. $\& 2421$ (Supp. 1986)) (transportation of persons across state boundaries for the purpose of prostitution).

63. See e.g., 18 U.S.C. § 922(b)(3) (1968). 
that the number of abortions performed in the United States would probably not be significantly diminished. Of course, whether the political climate at the time these issues come up would permit the weight of the federal government to be brought to bear against abortion in any way is yet another question.

\section{VI}

\section{Abortion Before RoE $V$. Wade}

Before Roe $v$. Wade, abortion seemed in some ways to be the easiest of the vice crimes for the police to inhibit. This was not because the consumers were indifferent to the activity. On the contrary, it is reasonable to believe that those who wanted an abortion wanted one very much and with considerable urgency. For those who were unmarried, the disadvantages of pregnancy were great in terms of loss of status in their families, schools, or immediate neighborhoods. For all, the inability to obtain an abortion meant the physical discomfort of pregnancy and childbirth, and the subsequent burden of an unwanted child. Though this latter problem could presumably have been alleviated by putting the baby up for adoption, this often involved a degree of shame; many regarded this behavior as irresponsible.

Nonetheless, despite what one might regard as the highly inelastic demand for an abortion, there were several factors militating against abortions prior to Roe $v$. Wade. First of all, the woman who did not want to bear a child had typically found out that she was pregnant through a medical test performed by a physician. This raised many difficulties. Her very request for a pregnancy test was an acknowledgment of her sexual activity at a time when society by no means took this for granted. Reluctance to take such a test often caused a delay, which reduced the relatively short time she had for the abortion to be performed safely.

The test was also expensive. The cost of about thirty dollars, including the fee for the doctor's visit, was presumably not enough to prevent the women from being tested, considering the high stakes involved. However, it was often expensive enough to delay the test until the likelihood of pregnancy was somewhat greater than it would have been just after the biologically necessary lapse of time for the test to be accurate. This, of course, also delayed the abortion.

Moreover, even in those cases where there was no expense, as where the testing was done free at a family planning clinic, there were problems. Since there simply were not many such clinics, the ones that did exist were often hard to reach, especially for women outside urban centers. Regardless of the clinic's location, it took some courage for the woman to be seen going into one.

Finally, if the woman "failed" the test, a member of "society" would know she was pregnant. From the viewpoint of enforcement, this tended to make abortion a little more like murder than the other vice crimes. In a murder case, even if the body has disappeared, the fact that someone knows of a victim may result in apprehension and would be, at the very least, a constant 
threat to the perpetrator. The social stigma attached to abortion was great, and many women who desired abortions did not know that it was not criminal for them to obtain one. In such a situation, the potential dissemination of the fact that one was pregnant must have been a significant deterrent to obtaining an abortion.

One study of 114 women who had procured illegal abortions in 1965 revealed that forty-four had gone to their regular doctors to ask for a pregnancy test. ${ }^{64}$ Fourteen of the forty-four refused to go back to these doctors, either because the doctors had refused to help them in their search for an abortion or because they feared the doctors would turn them in to the police. ${ }^{65}$ Seventeen of those who did not go to their regular doctors went to a doctor recommended by someone else, while an equal number selected a doctor at random from the telephone book or because of convenient location.66 Twenty-three other women sought to avoid detection or embarrassment by having the test done through other channels. ${ }^{67}$ Of these, nine took a urine sample to a laboratory or drugstore, while two more were fortunate enough to know someone who could do the test directly. ${ }^{68}$ Twelve others, often using false names and addresses, "used the relative anonymity of a local hospital or clinic to have a test made, to avoid meeting a doctor who might take a personal interest in the fact of the pregnancy." 69 Nine of the women in the study never went for a test. ${ }^{70}$

Once the woman knew she was pregnant, she often found it difficult to locate someone to perform the abortion. A major distinction between those who search for heroin and those who search for an abortion, both of whom have a relatively inelastic demand curve, is that the heroin addict typically is already familiar with how to obtain the drug and is part of a drug culture which spreads information among its members as to the drug's availability and how to avoid apprehension while procuring it. ${ }^{71}$ Before Roe $v$. Wade, the woman who sought an abortion, however, was often very much alone. She was not a repeat player herself and, hence, faced problems of information gathering in finding an abortionist. While virtually all addicts know other addicts, the person needing an abortion before Roe $v$. Wade typically knew of no one else who had obtained one. And where she did know another person who had contacted an abortionist, the nature of the market was such that the same contact might not work again. Furthermore, abandonment by the male partner often produced its own shock and immobility in the pregnant woman. The sudden requirement that the perhaps previously passive female take

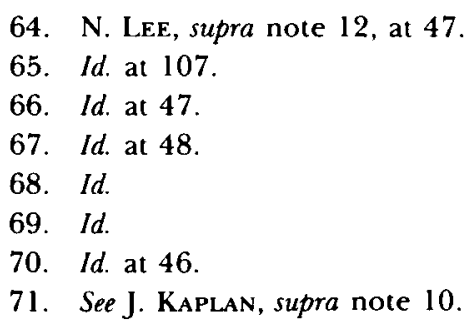


charge of the consequences of the pregnancy sometimes necessitated a major shift in orientation-and contributed to further delay and greater risk.

Perhaps the most important reason for whatever success the criminal law had in preventing abortion was a consequence of abortion being a medical procedure. Physicians as a group would seem to be extremely deterrable; if they are threatened with criminal punishment for performing a procedure, one would expect that they would comply with the law. After all, they have more legitimate income and higher status than the purveyors of virtually any other illegal goods or services, and hence have more to lose by conviction. Consequently, they have less to gain, compared to what they have to lose, from performing this relatively inexpensive operation. Being upper middle class and more forward-looking, physicians would seem to be more likely to calculate the costs and benefits of their actions and hence be more easily deterred by the criminal law from all but the most profitable forms of crime. Finally, physicians have been socialized into keeping records of all their operations, a behavior that would seem to make their activities easier to uncover.

The unwillingness of physicians to perform abortions did not mean that illegal abortions would not be performed. What it meant was that often abortions would be performed by less deterrable, nonmedical personnel or by medical personnel who charged a good deal to compensate them for the risk they were taking. In fact, an illegal abortion before Roe v. Wade cost $\$ 400$ to $\$ 500,{ }^{72}$ while today, thirteen years after the decision, the now legal procedure can be procured for as little as $\$ 80 .{ }^{73}$

Interestingly, the only two available studies of the question indicate that in the period before Roe $v$. Wade about 80 percent of illegal abortions were performed by physicians. ${ }^{74}$ Of course, these studies are hardly definitive. It is likely that the percentage varied greatly from area to area and from time to time, with the percentage performed by physicians increasing as public attitudes toward abortion changed.

Although the physicians performing abortions were probably more competent at it than were those without medical training, having the abortion performed by a physician did not necessarily mean that the job was competently done. The physician performing the abortion was more likely to be one of lower professional stature, inexperienced, and in a hurry as well. As a result, although an abortion, if legal, could be done with minimal medical risk, its illegal status made the procedure more physically dangerous because of a lack of skill of its practitioners and for various other reasons-even holding constant the later point in the pregnancy at which the illegal abortion tended to be performed.

72. See N. LEE, supra note 12 , at 95.

73. See Village Voice, June 30, 1987, at 109 (classified advertisement)

74. Schur, Abortion, Annals 136-47 (1968) (citing A. Kinsey \& M. Calderone, Abortion in the United States (1958)); P. Gebhard, Pregnancy, Birth, and Abortion 198-99 (1958). 
It is likely that all of these difficulties reinforced each other. The obstacles to being tested for pregnancy tended to postpone the search for an abortion; the difficulty of the search tended to postpone the finding of an abortionist; the later the abortion was performed, the more dangerous and difficult the procedure. In addition, the deterrence of medical personnel not only made the search for an abortionist more difficult and time-consuming, but often led to a situation where the abortionist was more likely to be unskilled. Both of these factors increased the danger of the operation, which in turn might have made the woman delay even further.

Nonetheless, the remarkable thing about the restrictions imposed by the pre-Roe $v$. Wade abortion laws is that some of the literature indicates they prevented only half of the abortions that would have taken place without them. ${ }^{75}$ This is the conclusion reached, as to one state, Hawaii, by Franklin Zimring, who compared the number of abortions the year after abortions became legal with the fall in the birth rate that year. He discovered that the number of legal abortions, all of which had been recorded, was twice the drop in the number of births. ${ }^{76}$ This fact, together with an examination of abortions and births among particular groups, led him to conclude that the number of abortions had less than doubled with the legalization of the procedure and, hence, that more than half that number of abortions had been taking place illegally before abortion had been legalized. ${ }^{77}$

Other estimates place the effect of the preliberalization of criminal laws in restraining abortion in the same general range. According to the sociologist, Edwin Schur, "it has been reported that police consider criminal abortion the third biggest illegal endeavor in the United States, surpassed only by gambling and narcotics . . . "78 Perhaps the best assessment of the prevalence of illegal abortion prior to Roe $v$. Wade is that of Whittemore, who, computing the number of abortions in the mid-1960's by a number of different means, concluded that "the oft-quoted figure of one million criminal abortions in the United States is a fairly reasonable estimate."79 This is threequarters the number of abortions reported in our most recent government statistics. ${ }^{80}$

There is no doubt, however, that the number of illegal abortions taking place before Roe v. Wade was surprisingly high. Part of the reason for this was the extreme difficulty of catching abortionists, even as compared to the perpetrators of the other vice crimes. First of all, the number of forbidden transactions needed to fulfill the entire demand for abortion in the United

75. See Zimring, Of Doctors, Deterrence, and the Dark Figure of Crime-A Note on Abortion in Hawaii, 39 Chi. L. Rev. 699, 717 (1972).

76. Id. at 706 .

77. Id. at 709 .

78. E. Schur, Crimes Without Victims, Deviant Behavior and Public Policy: Abortion, Homosexuality, Drug Addiction 25 (1965).

79. Whittemore, The Availability of Non-Hospital Abortions, in ABortion in a Changing World 217 (P. Hall ed. 1970).

80. See generally Center for Disease Control, Abortion Surveillance: Preliminary Analysis-United States, 1982-1983, 35 MORBIDITY \& MORTALITY WEEKLY REPORT 7SS (1986). 
States was markedly lower. Even the one and a half million abortions a year presently performed is less by a factor of at least one hundred than the number of purchases and uses of heroin by our 500,000 heroin addicts. The disparity is even greater with respect to marijuana, gambling, and, though it is hard to be sure, probably of prostitution, as well. This relative scarcity of criminal events makes it more difficult for the police to find those which do occur.

In the case of abortion, the illegal transactions were expensive, compared to the retail sales forbidden by most of the other vice laws. Thus, it paid the participants to take the kinds of precautions against discovery that would be uneconomical for less profitable sales; for a retail drug sale, it would not pay to have the purchaser wait on a certain street corner to be picked up and taken to a place which he did not know in advance to engage in the forbidden transaction. Yet, this was a common means of protecting the anonymity of the illegal abortionist.

Abortion was unusual among the vice crimes in that it did not involve contraband, the possession of which constituted a crime. Instruments necessary to induce abortions were probably present in most physicians' offices, plus those of many nonphysician medical workers. In addition, these instruments were freely available as items of commerce, durably capable of being used repeatedly, and easily adapted from other available materials. This not only made it more difficult to convict abortionists who were not caught in the act, it also promoted ease of entry into the illegal business. Presumably, there would be a great many more illegal retail dealers in all kinds of contraband, from drugs to illegal guns, if the supply could be easily obtained without risk.

In addition, the abortion industry, unlike that supporting drugs or gambling services, had a relatively nonhierarchical and undifferentiated structure. There were no producers, importers, wholesalers, and kilogram dealers above the retail level as there are in the illegal drug business. Nor were there the bankers, layoff bookies, telegraph services, enforcers, and the host of other specialized operators apart from the retail level, that comprise the illegal gambling industry.

This "industry structure" had a number of consequences for the enforcement of the abortion laws. First, it meant that the "yield" to law enforcement of infiltrating an organization was low; there were no "big cases" to be made. Moreover, the lack of a differentiated organization or a supply line of significant length greatly reduced the ability of law enforcement to disrupt the operation. In drug cases, where the police can seize money or expensive contraband, and in gambling cases, where they can seize money or betting slips, the interference with the ongoing business and the loss of working capital might injure the operation more than would criminal prosecution.

In these respects, illegal abortion was like another vice crime where the supply line was a very short one-prostitution. But prostitution, or at least 
street walking prostitution, is more risky because, in order to attract business, the street walkers must advertise their presence and, hence, become vulnerable to loitering arrests, decoy operations, or police harassment. In a way, abortion was more like the call-girl business, which is notoriously difficult for the police to suppress-despite the availability of vice squad officers to act as decoys. With respect to abortion, however, the decoys had to be womenwho were (and still are ) grossly underrepresented in police work.

Finally, in both prostitution cases and narcotics cases at the retail level, virtually everybody involved is also guilty of some other criminal activity, has a police record, or is dependent upon police goodwill in one way or another. Not only may they be coerced by the police into giving information and cooperating in investigations, but they are in no position to complain about the wholesale violations of their rights that routinely occur on the street.

The women who had obtained or were seeking abortions and those persons who performed abortions were likely to be in a different situation. The police not only had to be more careful in dealing with them, but were more likely to find it unrewarding. The women getting abortions tended to be loyal to those who had helped them; it was therefore difficult to find those who could be pressured into informing or acting as a decoy to allow the police to work their way up to "Mr. or Ms. Big." Finally, the class bias of police enforcement in this area worked against enforcement of the abortion laws. The seekers and performers of abortions and their allies were far more likely to be middle class and able to respond vigorously to the kinds of police abuse that was (and is) common in the enforcement of the other vice crimes.

In view of these difficulties, it is not surprising that the prosecution rate for abortion was low. But it was more than merely low, it was amazingly low. According to one authority:

In Alabama in the period 1894 to 1932, for example, there were forty indictments and five convictions; in Arkansas between 1921 and 1932, twenty-seven indictments and nine convictions; in Massachusetts between 1849 and 1858, thirty-two indictments and one conviction; in Michigan between 1893 and 1932, 156 indictments and forty convictions; in Minnesota between 1911 and 1930, 100 indictments and thirty-one convictions; and in Utah between 1896 and 1932 seventeen indictments and three convictions. By the same token, convicted abortionists were often dealt with leniently. A statistical analysis of all 111 convictions for abortion in New York County between 1925 and 1950 (about four convictions per year) indicates that 44 percent of those convicted were given probation. This is all the more remarkable when it is realized that 55 percent of these prosecutions were brought about because of a woman who was sufficiently ill after the abortion to arouse public notice and that in 10 percent of the cases the woman had died as a result of the abortion. ${ }^{81}$

81. K. LuKer, supra note 50, at 53-54. For a modern example of this phenomenon in Canada, see Court in Canada Rules on Abortion, N.Y. Times, Jan. 29, 1988, at Y3, col. 1. 
VII

\section{Illegal Abortion in Today's World}

\section{A. Technological Changes}

The world has changed considerably since Roe $v$. Wade, and it is unlikely new abortion laws comparable to those prevailing before 1973 would reduce the number of abortions to a level between the one-half and one-third as would be predicted from Zimring's study. ${ }^{82}$ First of all, technology has advanced considerably in the interim. The important technological advances have come in two areas: pregnancy testing and the performance of abortion itself.

So far as pregnancy testing is concerned, the expense, embarrassment, and delay a woman faces in finding out whether she is pregnant can be largely eliminated. There are already on the market several reliable home pregnancy testing kits. They cost about $\$ 10$ each, ${ }^{83}$ and are at least as sensitive as those used by physicians in 1973. Moreover, the development of home pregnancy tests is continuing. The tests have only been available for about ten years and are still being refined and made more sensitive, simpler to use, and perhaps even cheaper. One of these tests, the enzyme immunoassay test, can provide information that the user is pregnant on the same day as a missed menses. ${ }^{84}$ Nor is it likely that states will be able to interfere with the distribution of such tests; they are too useful for those who wish to bear children and who wish to begin prenatal care at the earliest time.

The second major area of technological advance has been in the performance of abortion itself. There is evidence that even illegal abortions were becoming much safer in the years before Roe $v$. Wade, as medical technology advanced. ${ }^{85}$. The much greater advances made while abortion has been legal make it very unlikely that the safety and ease of the operation would be reduced to a level close to that before Roe $v$. Wade.

The degree of technical advance in the performance of abortion has been somewhat surprising, considering that abortion, when legal, had long been a relatively simple and safe procedure. Probably the major reason why technical development in the area has been so rapid is the increase, after Roe $v$. Wade, in the number of abortions performed by licensed medical personnel. Observation and the kind of controlled experiments that could not take place when abortion was illegal, then, taught physicians a good deal about what they could and could not do efficaciously and safely.

Before Roe $v$. Wade the dominant means of abortion in the first trimester (which presently accounts for 91 percent of the abortions) was surgical

82. See Zimring, supra note 75 .

83. For example, VLI Co. Clearblue Test, OPC Co. Advance test.

84. See Brucker, What's New in Pregnancy Tests, $14 \mathrm{~J}$. OF Obstetric \& Neonatal Nursinc 358 (1985).

85. See Illegal Abortion: Deaths in the United States, 14 Family Planning Perspectives, May/June 1982, at 164. See C. Tietze \& S. Henshaw, supra note 13, at 131. 
abortion. ${ }^{86}$ This procedure, also called " $D$ and $C$ " (dilation and curettage), amounted to scraping out the fetus along with the lining of the uterus. First the woman's cervix was dilated by forcing into its opening a number of rods of gradually increasing diameter, one at a time, until an opening was made wide enough for the insertion of the curette, a kind of sharp metal scraper. ${ }^{87}$

Some of the dangers of this procedure are obvious. The forcible dilation of the uterine cervix or the scraping, or curettage, were likely to injure and even puncture the uterus wall if it was performed by an unskilled operator or even by a skillful one who was in a hurry. And, of course, when abortions were illegal, the abortionist often was in a hurry; for every extra minute spent on the operation increased the risk of being apprehended in the act. In addition, the abortionist typically performed the operation without complete anesthesia for two reasons. First, the doctor often did not have the proper facilities (including an assistant) to administer anesthesia, and, second, not using anesthesia reduces the possibility of an emergency requiring the patient's hospitalization, such as an allergic reaction. ${ }^{88}$ Not only did this make the procedure a painful one, but the inevitable twitches and jerks which the unanesthetized curettage caused made it more likely that injury would occur during the process. Incomplete currettment subjected the woman to the immediate dread of uncontrollable hemorrhage. Indeed, some "abortions" were done on nonpregnant women with menstrual disturbances. Injury of the small, firm uterus expected to be larger was frequent and resulted from failure to obtain the expected amount of material. Redoubled effort to complete the procedure often led to perforation injury.

Finally, this method of abortion was not even always available. Before abortion was practiced widely, the conventional wisdom was that the uterus became too large for $D$ and $C$ after the twelfth week of pregnancy. After the twelfth week of pregnancy, it was believed that abortions should be delayed until the sixteenth week, when saline abortion, a much more complicated procedure, could be used..$^{89}$

Today suction, or vacuum abortion, an entirely different procedure, is used in the great majority of first trimester abortions and even in abortions somewhat after this time.90 It is faster, less painful, and far less subject to complications than the older procedures. In a suction abortion, a thin, plastic tube, called a cannula, is inserted into the uterus. The cannula is attached to a small pump (or to a syringe) creating a vacuum which sucks out the lining of the uterus along with the fetus and membranes attached to it. ${ }^{91}$ Until the eighth week of pregnancy, the cervix may not even have to be dilated, since the cannula, at most 6 millimeters wide, and far smaller than the curette, is narrow enough to fit through the opening of the cervix softened by

86. See N. LEE, supra note 12 , at 93 .

87. See W. Hern, Abortion Practice 117-19 (1984).

88. See N. LEE, supra note 12 , at 85.

89. W. Hern, supra note 87 , at 123.

90. J. Hodgson, Abortion and Sterilization: Medical and Social Aspects 236 (1981).

91. W. HERN, supra note 87, at 111-16. 
pregnancy. Moreover, the plastic tube, being comparatively soft, is somewhat less likely to puncture the uterus. In fact, vacuum aspiration abortion may be used up to the fourteenth week of pregnancy, though this is slightly more complicated, since the cannula then is up to twelve millimeters in diameter and the cervix must therefore be dilated. By the fourteenth week, well over 90 percent of today's legal abortions will already have been performed. ${ }^{92}$

Technology has continued to advance in this area. A new drug known as RU-486 is currently being tested both in Europe and in Southern California. ${ }^{93}$ It is a steroid which blocks the action of progesterone, the body's hormone which prevents the uterus from expelling the fetus. In the absence of this hormone the fetus is expelled. The current understanding is that the drug has minimal side effects and is 80 percent effective when administered within the first six weeks of pregnancy. ${ }^{94}$ Research is continuing to provide new, safer, and easier means of producing an abortion. A combination of RU-486 and another drug has raised the percentage of successful abortions to 90 percent. RU-486, according to medical experts, is about one to five years from the commercial market. ${ }^{95}$

The importance of this drug and its successors is that it permits selfabortion at a time and place convenient to the woman. In fact, self-abortion with instruments even occurs occasionally today (presumably when the woman is completely without funds or fears discovery so much she is unwilling to appear even for a legal abortion) and is extremely dangerous. Performing the procedure through the use of drugs like RU-486 has transformed the enforcement of laws against abortion into an attempt to suppress a drug traffic. Since drugs, whether psychoactive or abortofacient, are easy to conceal and to sell on an illegal market, obtaining an illegal abortion will become as easy as purchasing an illegal drug.

\section{B. Social Changes}

Probably even more important than the technological advances since the time of Roe v. Wade have been the social changes in the United States. These changes fall into two related, but independently important categoriesinstitutional changes and changes in public consciousness.

Among the institutional changes since Roe $v$. Wade are the changes in the laws of other nations which have made abortion legal and easily available. For many women, these changes will make the availability of abortion simply a function of economics. Toward the end of the period before Roe $v$. Wade, women were already travelling in increasing numbers to foreign countries to get their abortions. ${ }^{96}$ At first, this was relatively uncommon, since most

92. See Abortion Surveillance: Preliminary Analysis-United States, 1982-1983, supra note 80 , at $8 \mathrm{SS}$ (1986).

93. See Kaye, Are You Ready for RU-486, The New Republic, Jan. 27, 1987, at 12.

94. Id. at 14 . 1.

95. Id. See also Drug Induced Abortions Now Possible, San Francisco Chron., June 8, 1988, at B4, col.

96. For a discussion of the case of one such woman see K. LUKER, supra note 50, at 62-65. 
countries had laws similar to those of the United States. (England first legalized most abortions in 1967.) Now, many countries have abortion laws as permissive as those in the United States today, and, in fact, serve many foreigners. (England, for instance, performs 20,000 abortions a year on women from Spain.) ${ }^{97}$

It is probably most important to note that, in Canada, abortion is legal.98 While legal or not, abortion is also easily obtainable in Mexico as well. ${ }^{99}$ And it is very likely that if a sufficient market develops, a number of Caribbean countries, which have in the past helped Americans evade their nation's laws, ${ }^{100}$ will do the same as to abortion. Moreover, the price of travel has declined sharply since 1973, thus making it even more likely that if abortion becomes less legally available in the United States, a much higher percentage of our population will be able simply to leave the country temporarily for their operations.

Those travelling abroad would include not only the very rich but also a considerable number of the middle class, and lower middle class. The poor, upon whom the anti-abortion law would fall most heavily, would of course have the fewest opportunities to get around the law by travelling to another country; but even for many of them, especially those who live close to our borders, the amount of money required would be minimal. ${ }^{101}$

Institutions within the United States have changed as well in the past fifteen years. At the time of Roe v. Wade, family planning agencies such as Planned Parenthood were scattered throughout the nation, but there were large numbers of women not served by any agency. According to one study, there were, in 1968,800 such agencies serving about 800,000 women. ${ }^{102}$ Now there are 4,200 agencies serving over 4.2 million women. ${ }^{103}$ Since these agencies do a great deal more now than merely provide abortions, they will likely remain in business even where abortion is illegal. And it is likely that, to the limits that the laws against aiding and abetting would allow, many of them would give emotional support to women seeking abortions. That is not to say that they would violate federal or state law. It is unlikely that any law would inhibit their providing home pregnancy tests on a large scale, counselling women on whether they can legally obtain an abortion in the United States, or

97. See C. Tietze \& S. Henshaw, supra note 13, at 52 (legal abortions carried out under the 1967 abortion act in England and Wales).

98. For a discussion of legal and illegal abortion in Canada, see Can. Crim. Code 251(1)(4) (Tremeear's 1987). See also Morgentaler v. The Queen, I S.C.R. 616 (1976); LAW Reform Commission of Canada, Abortion Reform: The Issues and Options (1988).

99. See N. LeE, supra note 12, at 5 .

100. For a discussion of the use of the Caribbean for the evasion of U.S. law, see R. BLum, Offrshore Haven Banks, Trusts, and Companies (1984).

101. The cost of a round trip bus fare from Los Angeles to Tijuana is under thirty-five dollars. From San Diego to Tijuana is approximately eight dollars.

102. See Organized Family Planning Services in the United States, 11 Fam. Plan. Persp., Nov/Dec. 1979, at 342 .

103. Id. 
perhaps even advising those who can afford the trip to leave the country for an abortion.

Moreover, unless the federal government criminalizes abortion throughout the nation, there would still be operational abortion clinics in those states which permit them. These would inevitably provide a network even for those women from out-of-state who are legally disabled by federal law from receiving abortions. Such women may nonetheless be able to seek out employees of the clinics who regularly perform legal abortions and may in some cases be able to convince them to break the law. It may well be much easier to induce trained personnel from these clinics to perform abortions on out-of-state residents than to find people to enter an entirely illegal business in a state that enforces its abortion law vigorously. This may be especially likely if, as is probable, the federal resources devoted to monitoring abortion on out-of-staters in states where abortion is generally legal may be stretched very thin. In addition, the legal abortion clinics are likely to provide a constant reservoir of trained abortionists who can work even in states that forbid abortion, though for the first few years that any such anti-abortion laws are in place, the reservoir of already trained employees will be quite large anyway.

Another change in the institutions of the United States since Roe v. Wade, or more precisely since about five years before that case, has been the development of large numbers of women's groups whose members believe quite passionately that women have a right (whether it is a constitutional or merely a moral right is not important) to an abortion should they desire one. ${ }^{104}$ It is very likely that these women would act not only as a support for those seeking abortion, but also as a conduit of information. One can argue that by helping women to obtain abortions, they would be aiding and abetting criminal acts and, hence, would render themselves criminally liable. It is not clear, however, how real the threat of prosecution would be and how many women will be so ideologically committed that they would be undeterred by the law.

The other change in the United States since the time of Roe v. Wade is perhaps even more fundamental than the institutional change. There has been a basic shift in popular consciousness on abortion. In 1965, only about 15 percent of the population believed in a right to abortion on demand. 105 Today, about half of the population supports such a right; ${ }^{106}$ and many of these people are passionate in their belief. This support for rights to abortion on demand will make the reenactment of anti-abortion laws in many states impossible and make major federal intervention in the area difficult.

One of the effects of the changes mentioned above will be the number of people willing to perform abortions. Today, one-half of the obstetric and gynocological residents in the United States are women. It is likely that

104. See K. LuKER, supra note 50, at 93-100.

105. See Opinion Roundup, supra note 6.

106. $I d$. 
physicians who perform illegal abortions in the future will not only be less marginal and more competent but more moved by ideology and compassion, and less by desire for profit. In addition, now that the stigma attached to performing abortions has been greatly reduced, regardless of the law, it may be predicted that many more physicians will be willing to cooperate in them. Certainly the formal nongovernmental sanctions against this conduct (such as expulsion from medical societies) will be rendered less likely.

\section{VIII}

\section{Criminal Enforcement of Anti-Abortion Laws}

Another effect of the change in consciousness as to abortion will be on those obtaining abortions. They will fear less the social stigma of being revealed, and presumably will be less willing to cooperate with investigation and prosecution of these cases. If, as also seems likely, the percentage of poorly performed abortions drops sharply too, there will be fewer women with even this reason to cooperate with the police, and thus fewer cases to come to police notice through routine medical channels.

Perhaps the most important effect, however, will be on the behavior of the legal system. Of course, it is unlikely that those performing abortions will be very much moved by the fact that prosecutors will find it very hard to come by juries to convict them. ${ }^{107}$ For all but zealots, the unpleasantness of arrest and the cost and stigma of standing trial are such that they are sufficient deterrents themselves. Nonetheless, the diminished likelihood of criminal conviction will almost certainly lower the deterrent effect of the law upon those undertaking to perform abortions.

Jury acquittals will have an even more dramatic effect on prosecutors and the police than on those threatened with prosecution. The difficulty of showing concrete results in terms of convictions will tend to make prosecutors more reluctant to prosecute abortionists and to dampen the willingness of the police to invest in investigations. This is not surprising. Experience with the enforcement of other vice crimes has shown that where the police must use informants and decoys to make their cases, they often lose enthusiasm for enforcement. ${ }^{108}$

Several factors, apart from the changes in public consciousness, make it more likely that law enforcement will lose heart in attempting to suppress abortion. The lower number of abortion complications would lower the number of cases coming to their attention through reports from hospitals and occasionally from coroners. The use of decoys, the other major way police apprehend abortionists, would be made much more difficult by the ease and speed of pregnancy testing. Any abortionist willing to invest the time and

107. An example from Canada illustrates this problem. Henry Mergentlaby, an operator of an abortion clinic, was tried four times and even though there was no doubt as to his actions, was acquitted by four different juries.

108. See H. PaCker, supra note 4. 
effort in taking precautions can require that his prospective client be tested for pregnancy in his presence before any further discussions take place. This would impose on the police the requirement not only that they use women as decoys, but also that they use women who are in fact in their first trimester of pregnancy. Finally, the fact that typically there is no significant amount of forfeitable property which the police can seize in abortion cases has become more important since the days of Roe $v$. Wade. Increasingly, funds received from forfeiture are being used to provide resources for law enforcement, and an incentive for police departments to devote more energy to the drug problem and less energy to the less "profitable" vice crimes such as abortion.

\section{IX \\ The Ultimate EfFect of Overruling RoE $V$. WADE}

The result of overruling Roe $v$. Wade would be to reintroduce abortion as a vice crime-and one especially hard to suppress, at that. Does this mean that all of the energy and passion spent in politicking by both the pro-choice and the pro-life sides will be wasted? The answer, on reflection, is perhaps more complicated than it might first appear. One might regard the abortion issue as a kind of zero sum game in which two groups, both of whom care passionately about the issue, are engaged. However, in fact, there are several dimensions along which the struggle can be measured.

First, regarding the number of abortions performed, it is the thrust of this article that because of the advance of technology and the nature of U.S. political institutions, no great change in the number of abortions would occur as the direct result of overruling Roe $v$. Wade and the statutory aftermath. That is not to say that in the long run, even the relatively ineffective enforcement of a criminal law will be without a somewhat more significant effect. Often a demand which seems quite inelastic in the short run turns out to be much more elastic over time. It is likely that even slight increases in the difficulty of abortion will be met by some increase in the use of contraception, some decrease in sexual activity, and some increase in childbearing. After all, it took some years for the nation to adjust to the system of available abortion allowed by Roe $v$. Wade. In 1974, the first full year after Roe v. Wade, 763,500 abortions were reported. 109 This number climbed steadily over the next seven years to a total of $1,300,800^{110}$ abortions in 1981 . Since then the number has been relatively stable, rising to the current level of about $1,500,000$ per year. ${ }^{111}$ It is likely that changes in overall fertility, absorption of women into the job market, in welfare policies, and in contraceptive methods will have more effect than does the legal treatment of abortion. ${ }^{112}$

109. See C. Tietze \& S. Henshaw, supra note 13 , at 40-41.

$110 . \quad$ Id.

111. Id.

112. The case of Romania probably indicates the short and long term effects of laws against abortion, though because of the high degree of police control in that country the effect is considerably exaggerated. In November 1966, without warning, the government, moved by 
The number of abortions, however, is not the only dimension by which groups may measure their success in this battle. Those on both sides of the issue care passionately and are engaged in a symbolic as well as a practical struggle. According to Kristin Luker in her superb and sensitive study of the issue, the basic dispute is over the proper role of women in our society.113 The "right-to-lifers" regard motherhood and the raising of a family as the most important function a woman can perform. Their entire ideology, including their views as to the proper purposes of sex and the nature of the fetus as a person entitled to human rights, follows from this premise. ${ }^{114}$ It is likely that not all right-to-lifers proceed from this ideological basis. Others have different reasons for considering the fetus a human life, rather than merely a "prospective life" and, hence, for regarding abortion as murder. All, however, hold their position as a moral one and often refer with some contempt to those in favor of abortion as "utilitarians." 115

On the other hand, those who are pro-choice espouse abortion on demand as a woman's right and regard motherhood as but one part of a woman's role. ${ }^{116}$ They regard abortion as a necessary means of controlling a woman's fertility so that she can perform adequately in the labor market as well as in her own family, should she choose to have one.

For anti-abortion advocates, overruling Roe $v$. Wade would be as much a symbolic victory as a victory in fact. It was the shock of that decision which galvanized many of them into action to begin with, ${ }^{117}$ even though many lived in states such as California and New York which had already liberalized their abortion laws. It is not clear whether Roe v. Wade increased anti-abortion advocates' commitment and militancy (1) by affronting them with the assertion that their political action, even if they undertook it, would be unavailing to criminalize abortion; (2) by giving free abortion, to which they were unalterably opposed, the especially high status of being written into the Constitution; or (3) by making the abortion issue so salient and publicly visible that they could no longer ignore it.

Which particular fact of Roe $v$. Wade triggered pro-life activism may be quite important in predicting the reaction to a situation where abortion, in the

dissatisfaction with the nation's low birth rate, abruptly changed its abortion policy. Abortion, which had been freely available for a fee of $\$ 2.00$, was banned. In addition, the government restricted access to contraception and increased allowances, tax benefits, housing benefits, and maternity leaves for parents, particularly those with two or more children. In one year, fertility rose from 14.3 births per thousand population in 1966, to 27.4 births per thousand population in 1967. Gradually, however, the fertility rates dropped and the number of abortions rose again so that by 1983 the birth rate had returned to precisely the 1966 level. In March of 1984, the government announced new and more vigorous efforts against abortion. See Berelson, Romania's 1966 Anti-Abortion Decree: The Demographic Experience of the First Decade, 33 Population Studies 209, 209-22 (1979); Tietelbaum, Fertility Effects of the Abolition of Legal Abortion in Romania, 26 Population Studies 401, 401-17 (1972); Romanian Population Policy, 10 Population \& Development Rev. 570, $570-73$ (1984).

113. See K. LukER, supra note 50, at 193-94.

114. Id. at 204-08.

115. Id. See also Lake, The Metaethical Framework of Anti-Abortion Rhetoric, 11 SIGNS 478, 478-99 (1986).

116. See K. LuKER, supra note 50, at 175-79.

117. Id. at $137-40$. 
great majority of cases, would be against the law but where most women who wished could nonetheless obtain one. It is likely that this situation would be deeply unsatisfying to them, but whether they would regard the symbolic victory as enough is hard to predict. One could, of course, say "some would-some wouldn't," but this is hardly helpful without some sense of the numbers and the commitment involved.

Nonetheless, several affronts to the anti-abortion forces would be removed by widespread criminal laws against abortion. First, the number of abortions reported by health and census authorities would no longer shock them. Under today's conditions, all of the 1,500,000 legal abortions are counted, classified, and published; the number itself is shocking to many people. Traditional vice crimes are not tallied nearly as well and must be estimated, a process far more easily disputed or ignored.

Next, the passage of anti-abortion laws, even if it caused no reduction in the number of abortions, would remove the feeling of complicity which has clearly bothered many of the "pro-lifers." One anti-abortion writer argued that political action was essential "to rid us of the guilt we involve ourselves in as a nation by permitting mass nationwide abortion to continue."118 Another author, even before Roe $v$. Wade, warned that a sense of complicity in legalized abortion could force those who oppose abortion to be "wholly alienated from the body politic"119 and predicated that legalizing abortion might cause revolution by anyone who refuses "to go on supporting a government which he thinks kills the innocent ...."120 This feeling is also evident in the rejection of the pro-choice stand that abortion is a personal matter and that no one is forced to have an abortion. "It is like telling someone in Nazi Germany, 'don't worry, your hands are clean. You don't have to guard the camps." "'121

Finally, anti-abortion activists desire the criminalization of abortion not only for its effect in directly lowering the number of abortions, but also for its educational, moral, and symbolic effects. The Reverend Edward Bryce, a member of the Catholic Bishops' Committee for Prolife Activities, asserts, "Given the important educative role that law has in a pluralistic society, [our abortion] policy is a powerful force in promoting the acceptance of abortion."122 Furthermore,

[t]hese days our pluralism itself, combined with the pressures of a homogenized national culture, results in the boundaries of morality being largely marked out by the boundaries of the law. To believe that this society can effectively insist on the value of fetal life while refusing to restrict legislatively any assault that a woman may choose on that value is to indulge in sociological fantasy. ${ }^{123}$

118. See H. Brown, Death Before Birth 156 (1970).

119. See Stith, A Secular Case Against Abortion, Commonweal, Nov. 12, 1971, at 153.

120. Id.

121. Id. (emphasis in original).

122. See E. Bryce, America 166 (1982).

123. Id. 
In other words, in the view of many right-to-lifers, abortion must be criminalized in order to correctly express the value society gives to human life.

The pro-choice advocates, on the other hand, would clearly be less happy with the situation than they are today. For them, overruling Roe v. Wade would be a symbolic defeat, not balanced by any compensating improvement, since but for the defeats on funding they have suffered, they have every reason to be satisfied with the status quo. For them, any comparison with the situation at the time of Roe $v$. Wade, or with 1965, before the state-by-state move to liberalize abortion laws began, is irrelevant. From the situation at the present time, overruling Roe $v$. Wade and any legislative response to this would represent a loss of ground both practically, and to a much greater extent, symbolically.

This symbolic defeat, moreover, will be felt not only by those with ideological and emotional investment in the pro-choice position, but also by those women, regardless of their ideological positions, who are getting an abortion. No matter how easy it will be to procure an illegal abortion, there is an inevitable loss of dignity in having to act surreptitiously and participate in a violation of the law.

For those committed to the pro-choice ideology, moreover, two other effects of the overruling of Roe v. Wade will also be of great concern. Whatever lowering there will be in the number of abortions obtained by women desiring them, it will come at the expense of the poor and the ignorant. This is an affront to their ideas of equality, over and above their views of women's rights.

Moreover, abortion, when illegal, will also be more dangerous than when legal. Nonetheless, the increased percentage of abortions performed by physicians pre-Roe $v$. Wade was important in decreasing the death rate, and this trend is likely to be accentuated as to any future illegal abortions. And, of course, to a considerable extent the changes in technology since Roe v. Wade will make this problem less serious. In fact, if Roe $v$. Wade is overruled, illegal abortions (aside from those which are self-induced with improvised instruments), will probably have a lower fatality rate than legal abortions did at the time of Roe $v$. Wade.

How the pro-choice faction will weigh their losses against what they have retained is not easy to predict. Again, views will differ, and determining in advance their center of gravity is extremely difficult. In one respect, however, the pro-choice faction will be clear losers if Roe v. Wade is overruled. They will be forced back into the political arena to defend what they believe is their inalienable right. Seeming far more involved in careers and other activities outside the home than are the anti-abortion activists, they may feel much more keenly the additional demands upon their time and energies, regardless of the ultimate results. 


\section{Conclusion: The American Compromise}

In a way, the overruling of Roe $v$. Wade, if it occurs, would produce a kind of pragmatic American compromise, intended and desired by no one, but not completely without precedent. Although society is adamantly opposed on moral grounds to addiction to opiates, methadone is given to large numbers of heroin addicts. While society is opposed on moral grounds to gambling, many states have lotteries, and indeed, gambling laws are not enforced in most of the others. Though hundreds of millions of dollars are spent attempting to suppress marijuana growth and importation, and each year some 500,000 people are arrested on marijuana charges, the drug is widely available in virtually every American high school and college. In one-third of the states, the use of the drug is not even a criminal offense; and in most of the rest of the nation, the jailing of a marijuana user or small-scale possessor is a rarity.

In short, if Roe v. Wade were overruled, political battles over abortion might arise on a scale not yet seen. Eventually, somewhat fewer abortions would probably take place than under conditions of complete legality. In addition, the change would be felt mostly by the poor and the ignorant. Nonetheless, most illegal abortions would take place at a cost and a danger substantially more similar to that of a legal abortion today than to that before Roe v. Wade.

It is true that the situation might reinforce the anti-abortion activist's view as to the role of women in society by withdrawing the Supreme Court's opposition and by having the state (or at least more states than the none of which do so today) explicitly take this position. On the other hand, if indeed the pro-lifers are correct in their view that members of the pro-choice faction are utilitarians, many of those in favor of legal abortions will feel that as a practical matter, despite their defeat on the symbolic level, they will be able to get much of what they want. Certainly, if the nation's experiences with enforcing laws against vice crimes is any indication, this will be the case.

Moreover, pro-choice activists may well take some comfort in the longrange effect of a symbolic but temporary victory over another vice. Prohibition, a law adopted in great part for symbolic effect, was later found to be, in its practical consequences, too much for society to bear. Whether the same will be true in the abortion area is, however, by no means clear. It can just as easily be argued that, if Roe v. Wade is overruled, abortion will be more like consensual homosexuality today. In some states it is legal. In others, due to the failure of the Supreme Court to intervene, ${ }^{124}$ it is still illegal but the laws against it are generally unenforced. An observer looking at the amount of homosexuality in the two categories of states would most likely be able to discern no difference, over and above the difference in moral climate between the two groups of states that had initially produced the differences in law.

124. See Bowers v. Hardwick, 478 U.S. 186 (1986). 
So long as those seeking abortions can still find them, pro-choice activists can devote their energies to attempting to convince the political bodies to act in accordance with their ideology. If accomplished, this political victory might be even sweeter than the one provided, as it were, free of charge by the Supreme Court. 
